\title{
Influence of Dietary Supplementation of Dried Azolla on the Growth Performance of Broiler Chickens
}

\author{
V. K. Ranjan ${ }^{1}$, S. P. Sahu ${ }^{1}$, S. Shekhar ${ }^{2 *}$, Sanjay Kumar ${ }^{3 *}$, \\ S. K. Singh ${ }^{4}$ and Rajni Kumari ${ }^{5}$
}

${ }^{1}$ Department of Livestock Production Management, BASU, Bihar Veterinary College, Patna, Bihar, India

${ }^{2}$ Krishi Vigyan Kendra, (ICAR-NNRI), Koderma, Jharkhand, India

${ }^{3}$ Department of Animal Nutrition, BASU, Bihar Veterinary College, Patna, Bihar, India

${ }^{4}$ H. C. Krishi Vigyan Kendra, Hazaribag, Jharkhand, India

${ }^{5}$ Department of Livestock and Fishery management, RECR-ICAR, Patna, Bihar, India

*Corresponding author

\section{A B S T R A C T}

\begin{tabular}{|l|}
\hline K e y w or d s \\
$\begin{array}{l}\text { Azolla, Body } \\
\text { weight gain, Feed } \\
\text { intake, Feed } \\
\text { efficiency, Broiler } \\
\text { chicken }\end{array}$ \\
\hline Article Info \\
\hline $\begin{array}{l}\text { Accepted: } \\
\text { 07 January } 2021 \\
\text { Available Online: } \\
\text { 10 February } 2021\end{array}$ \\
\hline \hline
\end{tabular}

The present study was conducted to evaluate the effect of dietary inclusion of dried Azolla on weight gain, feed intake and feed efficiency of broiler chicken. The study was conducted for a period of six weeks with 240 day-old commercial broiler chicks (Vencobb). The chicks were randomly allotted to four dietary groups $T_{1}, T_{2}, T_{3}$ and $T_{4}$. Each group comprised of two replicates of thirty birds each. Sun dried and ground Azolla at $0,2.5,5.0$ and $7.5 \%$ levels were incorporated in the rations for $\mathrm{T}_{1}, \mathrm{~T}_{2}, \mathrm{~T}_{3}$ and $\mathrm{T}_{4}$, respectively. Weekly average body weight of chicks did not showed significant influence between the treatment groups at the end of second and fifth week of age except at the end of first, third, fourth and sixth week of age $(\mathrm{P}<0.05)$ among treatment groups. The mean weekly body weight gain was significantly $(\mathrm{P}<0.05)$ affected only at third and fourth week of age due to the dietary inclusion of dried Azolla at different levels. Average weekly feed intake had not significant influence among treatments except in the second and fifth week of age by the dietary inclusion of dried Azolla. Average weekly feed efficiency had significant $(\mathrm{P}<0.05)$ effects only during the second and fourth week of age and in the remaining weeks, the values were statistically comparable among treatments. It was concluded that inclusion of dried Azolla in broiler feed up to $7.5 \%$ level without any adverse effect on the performance of broiler chicken.

\section{Introduction}

Poultry development has taken a quantum leap in the last three decades emerging from a near backyard practice to a venture of industrial promotion. In India, broiler industry is the fastest expanding component of agriculture registering $15 \%$ growth rate per annum and the annual growth rate of broiler production is much higher in comparison with many other developing countries. The increase in broiler production is in direct 
competition with growing human population for high energy cereal grains. There is inadequate supply of poultry feed ingredients both in terms of quantity and quality due to urbanization and decreased land availability. The wide gap between the availability and requirement of feed materials may have an adverse effect on broiler enterprise.

Greater emphasis has been given during the past two decades to identify the new feedstuffs to widen the feed recourse base, thereby to improve the efficiency and economic viability of broiler production. In spite of extensive research on utilization of unconventional feed stuffs of agricultural, industrial, animal and aquatic origin there is only limited scope on actual usage of such materials in poultry rations, because of seasonal and scattered availability, variable nutrient quality, poor storage conditions and the presence of anti-nutritional factors or toxins.

Recently there is an increased emphasis in the use of aquatic plants in poultry rations because the protein and other nutrient content in aquatic plants are comparable to certain leguminous plants. Aquatic plants offer relatively cheap alternative feed stuffs and have many potential uses such as human food, animal feed, compost and bio-fertilizers. Among the aquatic plants floating fresh water fern, Azolla pinnata is a good source of protein and it contains almost all essential amino acids, minerals like iron, calcium, magnesium, potassium, phosphorus, manganese etc., apart from appreciable quantity of vitamin A precursor beta carotene and vitamin $B_{12}$. It is capable of assimilating atmospheric nitrogen due to the presence of symbiotic algae in its leaves. It is also found to contain probiotics and biopolymers (Pillai et al., 2004). Azolla is one of the plant resources with high bio-mass and protein production and economically used as a feed stuff in broiler chicken (Parthasarathy et al., 2002 and Alalade and Iyayi, 2006). However, there seems to be paucity of studies on the effect of dietary inclusion of Azolla on the production performance of the broilers. Therefore, the present study was conducted to evaluate the Azolla (Azolla pinnata) on growth performance of commercial broiler chickens.

\section{Materials and Methods}

The present study was conducted at Livestock

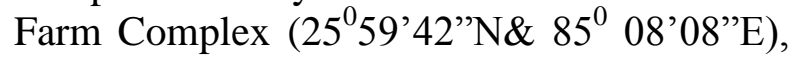
Bihar Veterinary College, Patna, Bihar, India.A total of 240, day-old Vencobb broiler chicks were randomly allotted to four treatment groups with two replicates of thirty birds each. Dried Azolla was included in the ration at $0 \%\left(\mathrm{~T}_{1}\right), 2.5 \%\left(\mathrm{~T}_{2}\right), 5.0 \%\left(\mathrm{~T}_{3}\right)$ and $7.5 \%\left(\mathrm{~T}_{4}\right)$. The chicks were reared under deep litter system of management. Standard management procedures were followed during the experimental period of 0-42 days (21 days for starter and 21 days for finisher phase). The birds were provided with feed and clean drinking water ad libitum throughout the experimental period. Proximate analysis of the rations was carried out according to procedures described by AOAC (1990) which have been presented in Table 1.

The body weight of individual bird was recorded at weekly interval. The amount of feed offered and refused was recorded daily and the feed consumed was determined. From these data, the average intake per bird per week was calculated for various treatment groups. Feed efficiency was calculated in each replicate based on the data on body weight gain and feed consumed.

Data recorded on various parameters were analyzed statistically using completely randomized design with the simple analysis of 
variance (ANOVA) technique (Snedecor and Cochran, 1994).

\section{Chemical composition of Azolla (DM basis)}

\begin{tabular}{|l|l|}
\hline Nutrients & Percentage \\
\hline Dry Matter & 90.92 \\
\hline Crude Protein & 25.61 \\
\hline Crude Fibre & 14.87 \\
\hline Ether Extract & 2.96 \\
\hline Nitrogen Free Extract & 32.18 \\
\hline Total Ash & 16.57 \\
\hline
\end{tabular}

\section{Results and Discussion}

The average body weight (g) of broiler chicken at weekly intervals influenced by different dietary treatments has been presented in Table 2. The results showed that the weekly average body weight gain of chicks did not reveal any significant effect between the treatment groups at the end of second and fifth week of age. However, there was significant $(\mathrm{P}<0.05)$ influence on average body weight gain of chicks among treatment groups at the end of first, third, fourth and sixth week of age.

This results of the present study are in accordance with the findings of (Parthasarathy et al., 2001a; Parthasarathy et al.,2002; Alalade and Iyayi, 2006; Shoukat et al., 2015; Mishra et al., 2016; Rai et al., 2016; Rout et al., 2017 and Sinha et al., 2018; Joysowal et al., 2018) wherein broiler birds received 5\% Azolla from $1^{\text {st }}$ to $5^{\text {th }}$ weeks of age had similar weight gain as that of control, while the birds on 10, 15 and 20\% Azolla diets had significantly $(\mathrm{P}<0.05)$ lower weight gain. On contrary, Basak et al.,2002 observed significant $(\mathrm{P}<0.01)$ improvement in live weight of broiler chicks than control diet fed birds when they were fed with 5\% Azolla meal by replacing seasame meal. They also observed that use of higher levels of Azolla meal (10 and 15\%) resulted in poor growth rate than control diet fed groups. The statistical interpretation of the results showed no significant difference in body weight among different dietary treatment groups.

The average weekly feed intake of broiler chicken influenced by dietary inclusion of dried Azolla is given in Table 3. The results on average feed intake at weekly intervals indicated that this trait was not statistically significant among treatments except in the second and fifth week of age.

Similarly, the average weekly feed intake of birds during the fifth week of age revealed significant $(\mathrm{P}<0.05)$ effects among the treatment groups. The birds maintained on $5.0 \%$ Azolla supplementation had significantly $(\mathrm{P}<0.05)$ lower feed intake than control, 2.5 and $7.5 \%$ Azolla fed groups. Similar to average weekly feed consumption, the average daily feed intake as influenced by dietary inclusion of various levels of dried Azolla had significant differences only at second and fifth week of age.

Table.1 Chemical composition of experimental rations (\% DM basis)

\begin{tabular}{|l|c|c|c|c|c|c|c|c|}
\hline \multirow{2}{*}{ Parameters } & \multicolumn{2}{|c|}{$\mathbf{T}_{\mathbf{1}}$} & \multicolumn{2}{c|}{$\mathbf{T}_{\mathbf{2}}$} & \multicolumn{2}{c|}{$\mathbf{T}_{\mathbf{3}}$} & \multicolumn{2}{c|}{$\mathbf{T}_{\mathbf{4}}$} \\
\cline { 2 - 10 } & Starter & Finisher & Starter & Finisher & Starter & Finisher & Starter & Finisher \\
\hline Moisture & 10.98 & 10.65 & 11.02 & 11.02 & 11.08 & 10.78 & 10.83 & 10.25 \\
\hline Crude protein & 22.60 & 18.77 & 22.40 & 18.92 & 23.16 & 19.28 & 22.80 & 19.03 \\
\hline Ether extract & 3.05 & 3.40 & 3.10 & 3.47 & 3.18 & 3.43 & 3.22 & 3.50 \\
\hline Crude Fibres & 4.20 & 4.80 & 3.95 & 4.96 & 4.17 & 4.87 & 4.30 & 5.10 \\
\hline NFE & 50.97 & 53.88 & 50.43 & 53.09 & 49.71 & 53.23 & 49.55 & 53.19 \\
\hline Total ash & 8.2 & 8.50 & 9.1 & 8.54 & 8.70 & 8.41 & 9.30 & 8.93 \\
\hline
\end{tabular}


Table.2 Average weekly body weight gain (g) of broiler chicken influenced by dietary inclusion of dried Azolla

\begin{tabular}{|c|c|c|c|c|c|}
\hline Age (weeks) & $\mathbf{T}_{\mathbf{1}}$ & $\mathbf{T}_{\mathbf{2}}$ & $\mathbf{T}_{\mathbf{3}}$ & $\mathbf{T}_{\mathbf{4}}$ & $\mathbf{S E M}$ \\
\hline $\mathbf{1}^{\text {st }}$ & 58.54 & 61.55 & 65.06 & 64.27 & 1.13 \\
& \pm 2.55 & \pm 2.28 & \pm 2.10 & \pm 2.16 & \\
\hline $\mathbf{2}^{\text {nd }}$ & 174.47 & 174.24 & 176.51 & 174.85 & 2.04 \\
& \pm 4.15 & \pm 3.90 & \pm 4.29 & \pm 3.91 & \\
\hline $\mathbf{3}^{\text {rd }}$ & $241.51^{\mathrm{a}}$ & $249.31^{\mathrm{ab}}$ & $278.92^{\mathrm{b}}$ & $248.50^{\mathrm{ab}}$ & 3.46 \\
& \pm 6.44 & \pm 7.64 & \pm 7.27 & \pm 6.01 & \\
\hline $4^{\text {th }}$ & $311.02^{\mathrm{a}}$ & $327.53^{\mathrm{ab}}$ & $357.29^{\mathrm{b}}$ & $330.09^{\mathrm{ab}}$ & 4.97 \\
& \pm 9.28 & \pm 9.94 & \pm 11.83 & \pm 8.92 & \\
\hline $\mathbf{5}^{\text {th }}$ & 427.65 & 450.41 & 443.23 & 452.29 & 6.65 \\
\hline $\mathbf{6}^{\text {th }}$ & \pm 13.28 & \pm 12.33 & \pm 15.34 & \pm 13.60 & \\
& 502.81 & 539.48 & 527.76 & 536.63 & 8.58 \\
\hline
\end{tabular}

Mean values bearing same superscript within a row did not differ significantly $(\mathrm{P}<0.05)$

Table.3 Average weekly feed intake (g) of broiler chicken as influenced by dietary inclusion of dried Azolla

\begin{tabular}{|c|c|c|c|c|c|}
\hline Age (weeks) & $\mathbf{T}_{\mathbf{1}}$ & $\mathbf{T}_{\mathbf{2}}$ & $\mathbf{T}_{\mathbf{3}}$ & $\mathbf{T}_{\mathbf{4}}$ & $\mathbf{S E M}$ \\
\hline $\mathbf{1}^{\text {st }}$ & 84.59 & 80.01 & 81.97 & 82.91 & 0.94 \\
& \pm 0.64 & \pm 1.28 & \pm 2.60 & \pm 2.35 & \\
\hline $\mathbf{2}^{\text {nd }}$ & $263.44^{\mathrm{ab}}$ & $273.56^{\mathrm{b}}$ & $247.11^{\mathrm{a}}$ & $276.63^{\mathrm{b}}$ & 4.97 \\
& \pm 4.76 & \pm 7.66 & \pm 2.15 & \pm 4.64 & \\
\hline $\mathbf{3}^{\text {rd }}$ & 417.81 & 426.32 & 435.09 & 405.05 & 5.33 \\
& \pm 10.41 & \pm 9.71 & \pm 12.96 & \pm 11.06 & \\
\hline $\mathbf{4}^{\text {th }}$ & 587.82 & 632.13 & 632.40 & 613.96 & 3.15 \\
\hline $\mathbf{5}^{\text {th }}$ & \pm 6.44 & \pm 4.90 & \pm 8.24 & \pm 5.89 & \\
\hline $\mathbf{6}^{\text {th }}$ & $833.91^{\mathrm{ab}}$ & $842.24^{\mathrm{b}}$ & $806.67^{\mathrm{a}}$ & $854.82^{\mathrm{b}}$ & 4.32 \\
& \pm 7.31 & \pm 5.98 & \pm 4.69 & \pm 4.21 & \\
\hline & 980.47 & 1041.19 & 1008.01 & 1041.06 & 15.93 \\
\hline
\end{tabular}

Mean bearing different superscript within a row differ significantly $(\mathrm{P}<0.05)$

Table.4 Average weekly feed conversion efficiency of broiler chicken as influenced by dietary inclusion of dried Azolla

\begin{tabular}{|c|c|c|c|c|c|}
\hline Age (weeks) & $\mathbf{T}_{\mathbf{1}}$ & $\mathbf{T}_{\mathbf{2}}$ & $\mathbf{T}_{\mathbf{3}}$ & $\mathbf{T}_{\mathbf{4}}$ & SEM \\
\hline $\mathbf{1}^{\text {st }}$ & 1.53 & 1.51 & 1.47 & 1.51 & 0.02 \\
& \pm 0.02 & \pm 0.03 & \pm 0.02 & \pm 0.04 & \\
\hline $\mathbf{2}^{\text {nd }}$ & $1.45^{\mathrm{a}}$ & $1.59^{\mathrm{ac}}$ & $1.71^{\mathrm{c}}$ & $1.52^{\mathrm{ab}}$ & 0.03 \\
& \pm 0.02 & \pm 0.05 & \pm 0.03 & \pm 0.06 & \\
\hline $\mathbf{3}^{\text {rd }}$ & 1.52 & 1.52 & 1.65 & 1.61 & 0.04 \\
& \pm 0.05 & \pm 0.04 & \pm 0.14 & \pm 0.07 & 0.02 \\
\hline $\mathbf{4}^{\text {th }}$ & $1.67^{\mathrm{ab}}$ & $1.63^{\mathrm{ab}}$ & $1.56^{\mathrm{a}}$ & $1.72^{\mathrm{b}}$ & \\
\hline $\mathbf{5}^{\text {th }}$ & \pm 0.05 & \pm 0.03 & \pm 0.03 & \pm 0.02 & 0.03 \\
\hline $\mathbf{6}^{\text {th }}$ & 1.76 & 1.83 & 1.94 & 1.93 & 0.04 \\
\hline
\end{tabular}

Mean bearing different superscript within a row differ significantly $(\mathrm{P}<0.05)$ 
The birds fed with 2.5 and $7.5 \%$ Azolla had significantly higher $(\mathrm{P}<0.05)$ daily feed intake than other treatment groups during second week. Whereas, in the fifth week, the Azolla fed groups $\left(\mathrm{T}_{2}\right.$ and $\left.\mathrm{T}_{4}\right)$ consumed significantly $(\mathrm{P}<0.05)$ more feed than control birds. The results of present study are in agreement withQuerubin et al., 1986, Alalade and Iyayi, 2006; Shojukat et al., 2015; Rout et al., 2017 and Lakshmanan et al., 2017 also observed that 10 and $15 \%$ Azolla meal in the diet of chicks significantly reduced the average weekly feed intake. But average weekly feed intake was similar, up to $5 \%$ Azolla meal inclusion in diets, to that of control diet. Differences in feed intake with addition of varying levels of Azolla in poultry rations observed by researchers are not consistent.

Variation in feed intake with changes in dietary ingredients as supported by Isshiki and Nakahiro (1989) could be the possibility for the numerical increase in daily feed intake noted in this study with Azolla fed groups. They stated that passage rate and feed intake changed based on type of feed ingredients used in formulating the diets. But, Bested and Morento (1985) stated that Azolla affected the palatability of the feed and reduced feed consumption.

The average weekly feed conversion efficiency of birds maintained on different dietary treatments is presented in Table-4. The mean weekly feed efficiency values showed that the different dietary levels of Azolla had significant $(\mathrm{P}<0.05)$ effects only during the second and fourth week of age and in the remaining weeks, the values were statistically comparable among treatments. In the second week the feed efficiency was best for control $\left(\mathrm{T}_{1}\right)$ group and it was statistically similar to $7.5 \%$ Azolla fed $\left(\mathrm{T}_{4}\right)$ group. The birds fed with $5.0 \%$ Azolla $\left(\mathrm{T}_{3}\right)$ had significantly inferior feed efficiency than control and $7.5 \%$ Azolla fed $\left(\mathrm{T}_{4}\right)$ groups.
Although the feed efficiency of $2.5 \%$ Azolla $\left(\mathrm{T}_{2}\right)$ fed group was poorer than control, the same was statistically similar to other Azolla supplemented groups during second week of age. The feed efficiency was best for 5.0\% Azolla $\left(T_{3}\right)$ fed group and it was statistically similar to control $\left(\mathrm{T}_{1}\right)$ and $2.5 \%$ Azolla fed $\left(\mathrm{T}_{2}\right)$ groups during forth week. The birds fed with $7.5 \%$ Azolla $\left(\mathrm{T}_{4}\right)$ had significantly $(\mathrm{P}<0.05)$ lower feed efficiency than $5.0 \%$ Azolla fed group $\left(\mathrm{T}_{3}\right)$.

Similar results were reported by Basak et al., 2002; Parthasarathy et al., 2002; Mishra et al., 2016 and Shukla et al., 2018who indicated that higher levels of Azolla (10 to 20\%) significantly reduced feed efficiency in broiler chicken. On the other hand, Ardakani et al., 1996 observed better feed efficiency in broiler birds fed with 6\% fresh Azolla compared to control birds.

However, Buckingham et al., (1978) reported that higher levels of acid detergent fibre (ADF), neutral detergent fibre (NDF) and lignin in Azolla could be the reason for the poor feed utilization in monogastric animals. However, in the present study maximum level of Azolla incorporation was $7.5 \%$. Based on the results of this experiment, it is clear that the dried Azolla could be used in broiler chicken ration up to $7.5 \%$ level without any adverse effect on feed efficiency.

In conclusion the results showed that dried Azolla could be used as an unconventional feed resource has a potential for use in diets of chicken. For the best performance, it can be included in broiler feed up to $7.5 \%$ level without any adverse effect on broilers. Dried Azolla has no deleterious effect on the palatability of the diets. Dried Azolla is a protein rich feed ingredient at low price and may be used in poultry feed to reduce the feed cost. 


\section{Acknowledgements}

The authors are acknowledged the farm facilities and financial assistance provided by Dean, Bihar Veterinary College, Patna for conducting the present study.

\section{References}

Alalade, O.A. and Iyayi, E.A. 2006. Chemical composition and feeding value of Azolla (Azolla pinnata) meal for egg type chicken. International Journal of Poultry Science 5(2): 137-41.

AOAC. 1990. Official Methods of Analysis. $15^{\text {th }} \mathrm{Edn}$. Association of Official Analytical Chemists, Washington, D. C.

Ardakani, M., Shivazad, H., Seyad Mehdizadeh, S.M. and Novrozian, H. 1996. Utilization of Azolla filiculoides in broiler nutrition. Journal of Agricultural Science 2(5-6): 35-46.

Basak, B.,Pramanik. A.H., Rahman, M.S., Tarafdar, S.U. and Roy, B.C. 2002. Azolla (Azolla pinnata) as a feed ingredient in broiler ration. International Journal of Poultry Science 1(1-3): 29-34.

Bested, S.B. and Morento, S.E. 1985. The effect of different percentage of Azolla on fattening pigs. MSACJournal (Philippines)17:31-40

Buckingham, K.W., Stephen, W.E., James, G.M. and Goldman, C.R. 1978. Nutritive value of the nitrogen fixing aquatic fern Azolla filliculoides. Journal of Agriculture Food Chemistry 26(5): 1230-34.

Isshiki, Y. and Nakahiro, Y. 1989. Feed digestibility in different intestinal parts of chicken. Japanese Journal of ZootechniqueScience 60(12): 1082-92.

Joysowal, M., Aziz, A., Mondal, A., Singh, S.M., Siddhnath, S.B., Chirwatkar, C. and Chhaba, B. 2018. Effect of Azolla (Azolla pinnata) feed on the growth of broiler chicken. Journal of Entomology and Zoology Studies, 6(3): 391-93.

Khatun, A., Ali, M.A. and Dingle, J.G. 1999. Comparison of the nutritive value for laying hens of diets containing Azolla (Azolla pinnata) based on formulation using digestible protein and digestible amino acid versus total protein and total amino acid. Animal Feed Science and Technology 81: 43-56.

Lakshmanan, A., Kumar, K. and Latha, P. 2017. Azolla- A low cost and effective feed supplement to poultry birds. International Journal of Current Microbiology and Applied Sciences 6(8): 3622-27.

Mishra, D.B., Roy, D., Kumar, V., Bhattacharyya, A., Kumar, M., Kushwaha, R. and Vaswani,S. 2016. Effect of feeding Azolla (Azolla pinnata) meal on the performance, nutrient utilization and carcass characteristics of Chabro chicken. Indian Journal of Poultry Science 51(3): 259-63.

Parthasarathy, R., Kadirvel, R. and Kathaperumal, V. 2001a. Studies on economics of utilizing Azolla in broiler rations. Cheiron 30 (1/2): 24-26.

Parthasarathy, R., Kadirvel, R. and Kathaperumal, V. 2002. Azolla as a partial replacement for fishmeal in broiler rations. Indian Veterinary Journal 79(2): 144-46.

Pillai, PK., Premalatha, S. and Rajamony, S. 2004. Azolla: A sustainable feed substitute for livestock. Spice India10: 39-46.

Rai,R.B., Dhama, K., Damodaran, T., Hamid, A., Rai,S., Singh, B. and Bhatt, P. 2012. Evaluation of Azolla (Azolla pinnata) as a poultry feed and its role in poverty alleviation among landless people in Northern plains of India. Veterinary Practice s13(2): 250-54.

Rout, S.K., Pradhan, C.R., Mishra, S.K., Pati, 
P.K. and Bagh, J. 2017. Performance of coloured synthetic broiler chicken fed dried Azolla as protein substitute. International Journal of Current Microbiology and Applied Sciences6(12): 2349-58.

Shoukat, Ara, Adil, S., Banday, M.T. and Khan, M.A. 2015. Feeding potential of aquatic fern-Azolla in broiler chicken ration. Journal of Poultry Science and Technology3(1): 15-19.

Snedecor, G.W. and Cochran, W.G. 1994. Statistical Methods. $8^{\text {th }}$ Edition, Iowa State University Press, Iowa.
Shukla, M., Bhattacharyya, A., Shukla, P.K., Roy, D., Yadav, B. and Sirohi, R. 2018. Effect of Azolla feeding on the growth, feed conversion ratio, blood biochemical attributes and immune competence traits of growing turkeys. Veterinary World, 11(4): 459-63.

Sinha, B.S., Kumar, S. and Chudhary, G.K.2018. Use of fresh Azolla as dietary supplementation in backyard poultry. International Journal of Current Microbiology and Applied Sciences 7: 1358-61.

\section{How to cite this article:}

Ranjan, V. K., S. P. Sahu, S. Shekhar, Sanjay Kumar, S. K. Singh and Rajni Kumari. 2021. Influence of Dietary Supplementation of Dried Azolla on the Growth Performance of Broiler Chickens. Int.J.Curr.Microbiol.App.Sci. 10(02): 706-712. doi: https://doi.org/10.20546/ijcmas.2021.1002.085 